\title{
EVALUATION OF POSITIVE END-EXPIRATORY PRESSURE THERAPY IN THE ADULT RESPIRATORY DISTRESS SYNDROME*
}

\author{
E.G. KInG, M.D., F.R.C.P.(c), R.L. Jones, PH.D., AND D.A. Patakas, M.D.
}

HXPOXAEMIC RESPIRATORY FAILURE occurring in association with a wide variety of antecedent illnesses has been termed the Adult Respiratory Distress Syndrome (ARDS) and is being recognized with increasing frequency. ${ }^{1-4}$ It is characterized by low partial pressure of arterial oxygen $\left(\mathrm{PaO}_{2}\right)$ and increased right-to-left shunt (Q் $s / \dot{Q} t)$, dead space ventilation, and lung stiffness. Many of these patients require controlled mechanical ventilation with 100 per cent oxygen, thereby risking the added problems of oxygen-induced pulmonary dysplasia. ${ }^{5}$ Recently, it has been demonstrated that $\mathrm{PaO}_{2}$ can be increased and that the inspired oxygen concentration required to produce a haemoglobin-saturating $\mathrm{PaO}_{2}$ reduced in this syndrome by application of positive end-expiratory pressure (PEEP $)^{6-11}$; in fact, this ventilatory modality has been suggested to be the mainstay of treatment. ${ }^{4}$ Three commercially available ventilators (Bennett MA-1, Ohio 560, and Engstrom) have mechanisms for the provision of PEEP and increased use of this means of support in clinical practice is to be anticipated. It is recognized that elevation in mean intrathoracic pressure may seriously compromise cardiac output, ${ }^{10}$ and, although the haemodynamic effects of PEEP in ARDS patients are allegedly small, ${ }^{4,6,7}$ there is conflicting evidence on this point. ${ }^{8,9,11}$ With the nonlinear relationship between $\mathrm{PaO}_{2}$ and $\mathrm{O}_{2}$ content, diminution in cardiac output can be predicted to reduce net oxygen delivery to tissues in patients operating on the flat upper part of their haemoglobin dissociation curve, thus negating, at least in part, some of the potential benefits of PEEP therapy.

This study was undertaken to ascertain the effects, in eleven ARDS patients, of $5,10,15$, and $20 \mathrm{~cm} \mathrm{H}_{2} \mathrm{O} \mathrm{PEEP}$ in contrast to conventional intermittent positive-pressure breathing (IPPB) support with constant volume ventilation on $\mathrm{PaO}_{2}$, right atrial blood partial pressure of $\mathrm{O}_{2}\left(\mathrm{PvO}_{2}\right)$, partial pressure of arterial carbon dioxide $\left(\mathrm{PaCO}_{2}\right), \mathrm{pH}$, cardiac output $(\mathrm{CO})$, Q $\mathrm{s} / \mathrm{Q} t$, dynamic compliance $\left(\mathrm{C}_{\mathrm{dyn}}\right)$, dead space ventilation $\left(\mathrm{V}_{\mathrm{D}} / \mathrm{V}_{\mathrm{T}}\right), \mathrm{O}_{2}$ delivery, and mean peripheral capillary oxygen tension $\left(\overline{\mathrm{PcO}_{2}}\right)$.

\section{METHODS}

Patients: Table I outlines relevant clinical data. None of the patients had a history of previous respiratory failure. All were haemodynamically stable and

\footnotetext{
${ }^{*}$ From the Department of Medicine and the Surgical-Medical Research Institute, University of Alberta, Edmonton, Canada. Supported by Medical Research Council of Canada grant MA-4220, and a Special Services and Research grant from the University Hospital, Edmonton. Presented in part at the Canadian Thoracic Society Annual Meeting, June 28, 1972, Halifax, Nova Scotia, Canada.

Please address reprint requests to: Dr. E.G. King, Department of Medicine, University of Alberta, Edmonton, Canada.
} 


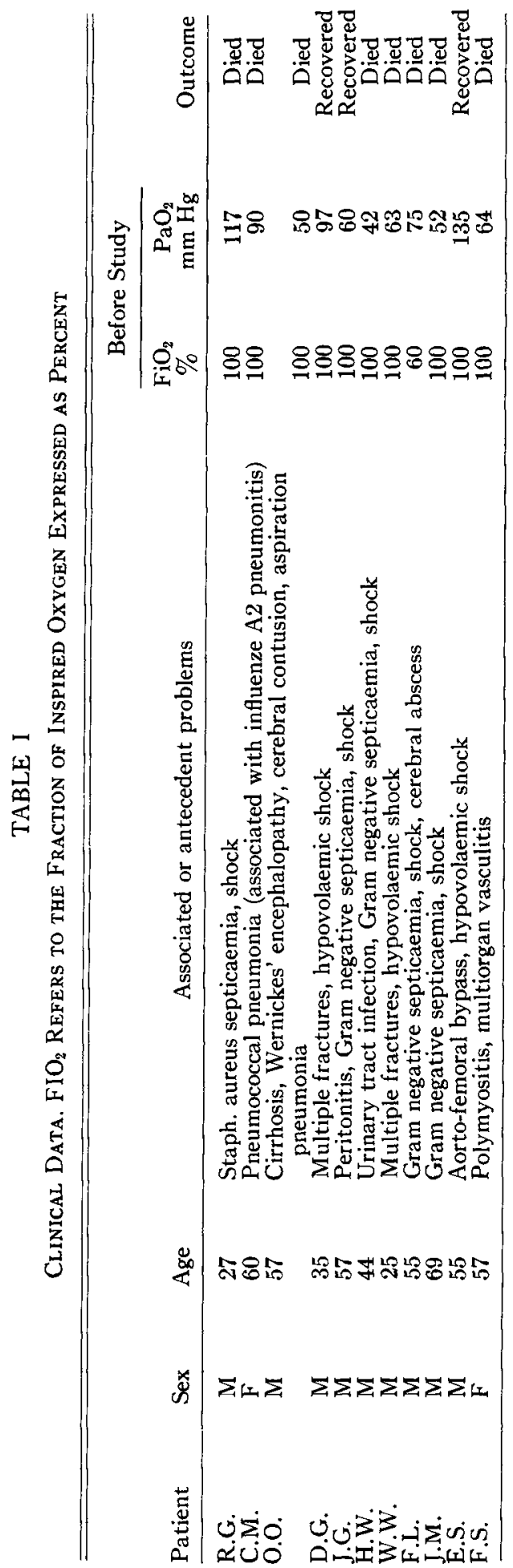




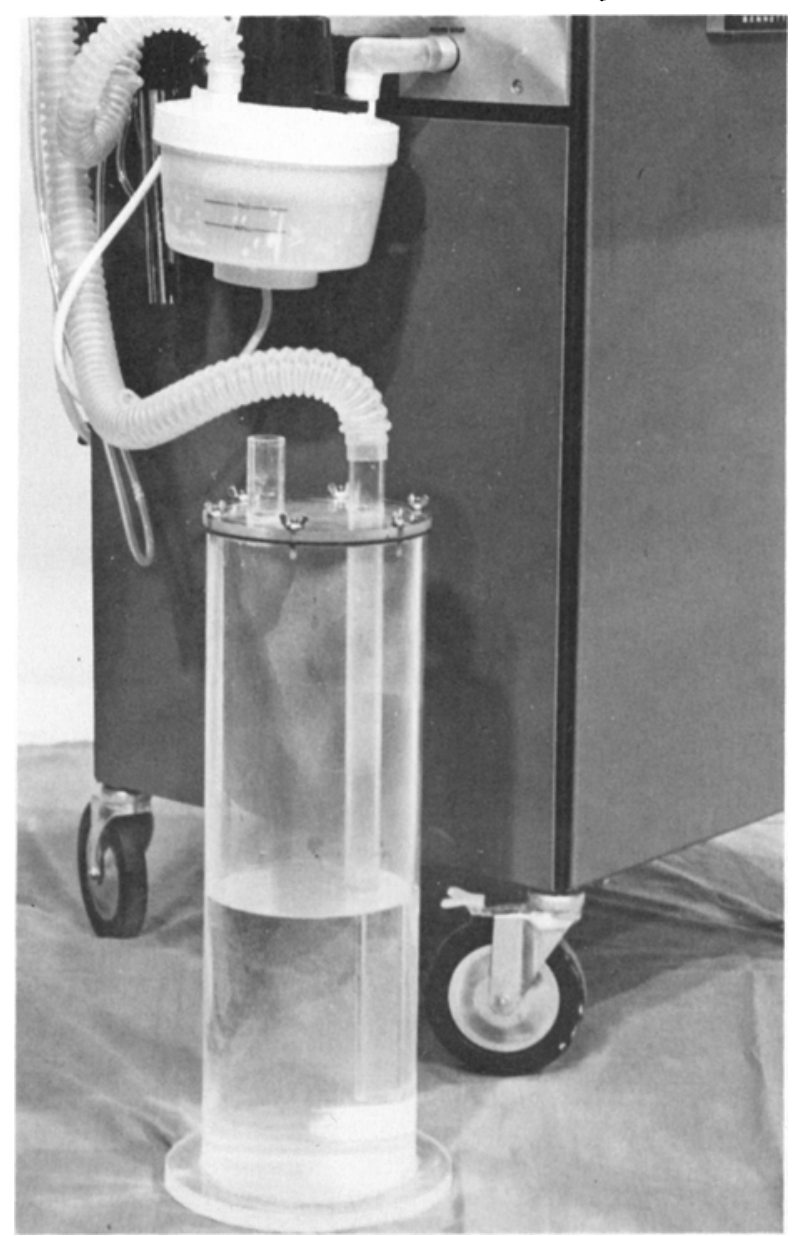

FIgure 1. Graduated plexiglass PEEP chamber connected downstream from the expiratory valve of the ventilator.

euhydrate when studied, and had alveolar-arterial $O_{2}$ gradients of at least 450 mm Hg with a measured Q $\mathbf{s} / \dot{Q} t$ of 20 per cent or greater. Patients in clinical shock, those with panlobar emphysema or blebs, and patchy necrotizing pneumonias were excluded from this study. Chest X-rays showed the presence of bilateral homogeneous alveolar infiltrates. All patients were studied with cuffed $7 \mathrm{~mm}$ Portex tracheostomy tubes, aortic catheters (green Kifa placed by femoral Seldinger technique), and right atrial catheters in place. None had chest tubes. They were supported with controlled constant volume mechanical ventilation (either Bennett MA-1 or Ohio 560) at tidal volumes of $12-18 \mathrm{cc} / \mathrm{Kg}$, and, with the exception of patient F.L., all were maintained on 100 per cent oxygen.

PEEP: End expiratory pressure was provided at the desired level by immersing a wide bore tube from the ventilator's expiratory port under a measured level of water (Figure 1). Expired gas was collected above the water from the enclosed PEEP chamber for determination of partial pressure of expired $\mathrm{CO}_{2}\left(\mathrm{PECO}_{2}\right)$. 
Protocol: After baseline determination of $\mathrm{PaO}_{2}, \mathrm{PvO}_{2}, \mathrm{PaCO}_{2}, \mathrm{pH}, \mathrm{CO}, \dot{\mathrm{Q}} \mathrm{s} / \dot{\mathrm{Q}} \mathrm{t}$, $\mathrm{C}_{\mathrm{dyn}}, \mathrm{PcO}_{2}$ and $\mathrm{O}_{2}$ delivery on IPPB, patients were placed successively on 5,10 , 15 , and $20 \mathrm{~cm} \mathrm{H}_{2} \mathrm{O}$ PEEP for periods of 20 minutes, with return to IPPB for 15 minutes between each PEEP application. All measurements except $V_{D} / V_{T}$ were made in 11 patients: dead space to tidal volume ratio was measured in five of these. In one patient (F.L.), who was on 60 per cent oxygen, shunt was determined with and without PEEP, when the inspired oxygen concentration was increased for 15 minutes to 100 per cent. The order of PEEP application was changed from $5,10,15$, and 20 , to $15,5,20$, and 10 in three patients. Measurements on $20 \mathrm{~cm} \mathrm{H} \mathrm{H}_{2} \mathrm{O}$ PEEP were not made in two patients as their $\mathrm{PaO}_{2}$ response to 5,10 , and $15 \mathrm{~cm} \mathrm{H}_{2} \mathrm{O} \mathrm{PEEP}$ was poor and it was felt that study on a higher PEEP level could not be justified.

Measurements and Calculations: $\mathrm{PaO}_{2}, \mathrm{PvO}_{2}, \mathrm{PaCO}_{2}$ and $\mathrm{pH}$ were measured with an Instrumentation Laboratories 113 system and haemoglobin saturations $\left(\mathrm{SO}_{2}\right)$ were determined from the standard Severinghaus nomogram.

Cardiac output was measured by dye dilution technique (indocyanine green, Waters XC 302 cuvette, X 302 densitometer and CO-4 computer) with injection into the right atrial catheter and withdrawal through the aortic Kifa catheter.

Right-to-left shunt was estimated from the standard shunt equation with the patient on 100 per cent oxygen.

$$
\dot{\mathrm{Q}} \mathrm{s} / \dot{\mathrm{Q}} \mathrm{t}=\mathrm{Cc}_{2}-\mathrm{CaO}_{2} / \mathrm{CcO}_{2}-\mathrm{CvO}_{2}
$$

where: $\mathrm{CcCO}_{2}=$ theoretical $\mathrm{O}_{2}$ content of pulmonary end-capillary blood $\left(\mathrm{ml} \mathrm{O} \mathrm{O}_{2} /\right.$ $100 \mathrm{ml}$ blood), the partial pressure of which was assumed to be the same as alveolar $\mathrm{PO}_{2}\left(\mathrm{PAO}_{2}\right)$. $\mathrm{Cc}_{2} \mathrm{O}_{2}$ was thus calculated from: $\left(\mathrm{Sć}_{2} / 100 \times 1.34 \times\right.$ haemoglobin concentration $)+\left(\mathrm{PAO}_{2} \times 0.0031\right)$; where $\mathrm{PAO}_{2}$ was equal to the barometric pressure $\left(\mathrm{P}_{\mathrm{B}}\right)^{*}-\left(\mathrm{PaCO}_{2}+\right.$ partial pressure of water vapour $)$ and haemoglobin concentration was measured by standard ferricyanide technique.

$\mathrm{CaO}_{2}$ and $\mathrm{CvO}_{2}=\mathrm{O}_{2}$ contents of arterial and right atrial blood respectively $(\mathrm{ml} \mathrm{O} / 2 / 100 \mathrm{ml}$ blood $)$. These values were calculated from: $\left(\mathrm{SaO}_{2}\right.$ or $\mathrm{SvO}_{2} / 100 \times$ $1.34 \times$ haemoglobin concentration $)+\left(\mathrm{PaO}_{2}\right.$ or $\left.\mathrm{PvO}_{2} \times 0.0031\right)$.

$\mathrm{O}_{2}$ delivery was calculated from $\mathrm{CO} \times \mathrm{CaO}_{2}$. Mean peripheral capillary oxygen tensions were estimated by using the Bohr integration procedure as modified by Riley and Cournand, ${ }^{12}$ and adopted for use in the peripheral capillary beds by Flenley.13

Systemic arterial pressure (SAP) and right atrial pressure (RAP) were continuously recorded by Statham P37 transducers and Hewlett-Packard 8800 series preamplifiers and multichannel recorder.

$\mathrm{C}_{\text {dyn }}$ was derived from the expired tidal volume (measured by a Wright spirometer, the mean of three readings being used) divided by the peak airway pressure (measured by the ventilator's pressure gauges with calibration checked against a Statham PM-5 differential transducer and standard pressure system) minus the level of PEEP being applied.

$\mathrm{PECO}_{2}$ was measured along with simultaneously drawn arterial samples for $\mathrm{PaCO}_{2}$ in five patients. Expired gas was bag-collected and analyzed for $\mathrm{CO}_{2}$ by Godart capnograph calibrated full scale from $1-5$ per cent. $\mathrm{PECO}_{2}$ was calculated

\footnotetext{
${ }^{*}$ Mean $P_{B}$ in Edmonton (altitude 2,200 feet) is $700 \mathrm{~mm} \mathrm{Hg}$.
} 
TABLE II

Changes in $\mathrm{P}_{\mathrm{a}} \mathrm{O}_{2}(\mathrm{~mm} \mathrm{Hg})$ Associated with $0,5,10,15$, and $20 \mathrm{~cm} \mathrm{H}_{2} \mathrm{O}$ PeEP.

\begin{tabular}{|c|c|c|c|c|c|c|c|c|c|}
\hline Patient & IPPB & $5 \mathrm{~cm}$ & IPPB & $10 \mathrm{~cm}$ & IPPB & $15 \mathrm{~cm}$ & IPPB & $20 \mathrm{~cm}$ & IPPB \\
\hline R.G. & 117 & 122 & 94 & 153 & 186 & 245 & 90 & 294 & 123 \\
\hline G.M. & 90 & 86 & 86 & 77 & 74 & 76 & 73 & 164 & 73 \\
\hline 0.0 & 50 & 53 & 47 & 59 & 51 & 71 & 52 & 106 & 57 \\
\hline D.G. & 97 & 132 & 100 & 131 & 114 & 118 & 114 & - & - \\
\hline J.G. & 62 & 76 & 64 & 58 & 66 & 83 & 80 & 117 & 128 \\
\hline H.W. & 42 & 40 & 45 & 38 & 37 & 40 & 36 & 54 & 39 \\
\hline W.W. & 63 & 127 & 89 & 191 & 55 & 297 & 103 & 297 & 102 \\
\hline F.L. & 75 & 79 & 96 & 96 & 85 & 91 & 98 & - & $\overline{-\alpha}$ \\
\hline J.M. & 52 & 72 & 65 & 78 & 63 & 72 & 60 & 136 & 59 \\
\hline E.S & 135 & 125 & 132 & 163 & 109 & 199 & 139 & 382 & 133 \\
\hline F.S. & 64 & 137 & 61 & 215 & 129 & 345 & 54 & 160 & 59 \\
\hline $\begin{array}{l}\text { Mean } \\
\text { S.D. } \\
\text { P. }_{1}\end{array}$ & $\begin{array}{l}77.0 \\
29.5 \\
-\quad\end{array}$ & $\begin{array}{r}95.4 \\
34.4\end{array}$ & $\begin{array}{r}81.5 \\
26.9\end{array}$ & $\begin{array}{r}114.5 \\
59.3 \\
0.04195\end{array}$ & $\begin{array}{r}88.0 \\
43.3\end{array}$ & $\begin{array}{r}148.8 \\
104.8\end{array}$ & $\begin{array}{r}81.7 \\
30.7\end{array}$ & $\begin{array}{l}190.0 \\
108.7\end{array}$ & $\begin{array}{r}85.9 \\
35.8 \\
\text { N.S. }\end{array}$ \\
\hline $\mathrm{P}_{2}$ & & & \multicolumn{2}{|c|}{0.04703} & \multicolumn{2}{|c|}{0.04469} & \multicolumn{2}{|c|}{0.00478} & \\
\hline
\end{tabular}

from $\left(P_{\mathrm{B}}-\mathrm{P}_{\mathrm{H}_{2} \mathrm{O}}\right) \times$ capnograph readout $/ 100 . \mathrm{V}_{\mathrm{D}} / \mathrm{V}_{\mathrm{T}}$ was then derived from the Böhr equation: $\mathrm{PaCO}_{2}-\mathrm{PeCO}_{2} / \mathrm{PaCO}_{2}$.

\section{Results}

$\mathrm{PaO}_{2}$ (Table $\mathrm{II}^{*}$ ): Mean $\mathrm{PaO}_{2}$ rose with increments in PEEP, the response curve being best described by a parabolic regression (Figure 2). The degree of change in $\mathrm{PaO}_{2}$ from one PEEP level to another between patients was variable. $\mathrm{PaO}_{2}$ fell slightly in three patients (G.M., H.W., E.S.) on $5 \mathrm{~cm} \mathrm{H}_{2} \mathrm{O}$ PEEP and two of these patients as well as one other (J.G.) demonstrated a fall in $\mathrm{PaO}_{2}$ when $10 \mathrm{~cm} \mathrm{H}_{2} \mathrm{O}$ PEEP values were compared to inter-PEEP IPPB measurements. $\mathrm{PaO}_{2}$ rose significantly above baseline IPPB levels in all but two patients (G.M. and H.W.) on 15 and $20 \mathrm{~cm} \mathrm{H}_{2} \mathrm{O}$ PEEP. Some patients required PEEP levels of 15 or $20 \mathrm{~cm} \mathrm{H}_{2} \mathrm{O}$ to improve their $\mathrm{PaO}_{2}$ (e.g. G.M., J.G.) and one patient (F.S.) demonstrated a decline in $\mathrm{P}_{\mathrm{a}} \mathrm{O}_{2}$ on $20 \mathrm{~cm} \mathrm{H}_{2} \mathrm{O}$ PEEP when compared to the $15 \mathrm{~cm} \mathrm{H}_{2} \mathrm{O}$ PEEP value. Another patient (H.W.) failed to show significant improvement in $\mathrm{PaO}_{2}$ regardless of the level of PEEP applied.

$\dot{Q} s / \dot{Q} t$ (Table III). Patients in this study were very ill as evidenced by a mean baseline shunt of 45 per cent and the fact that only three of the eleven survived. Mean calculated shunt decreased significantly with successive PEEP increments (Figure 3), although, again, variation between individuals was evident. The fall in shunt with PEEP was both real and CO-related as judged from $\mathrm{PvO}_{2}$ values.

$\mathrm{CO}$ (Table IV): With the exception of $5 \mathrm{~cm} \mathrm{H}_{2} \mathrm{O}$ PEEP, mean $\mathrm{CO}$ significantly declined with increasing PEEP levels (Figure 4). Variation occurred be-

\footnotetext{
- For all data tables, multicentered comparisons were done using the hotelling $t^{2}$ test (B.J. Winter, Statistical Principles in Experimental Design, McGraw Hill Book Company, New York, 1971). The computer program was taken from the DERS program Documentation 360/67. $P_{1}$ refers to comparisons between baseline IPPB values and subsequent measurements on PEEP: $P_{2}$ refers to comparisons between inter-PEEP IPPB values and the subsequent measurements on PEEP. NS $=$ not significant $(\mathrm{P}>0.05)$.
} 


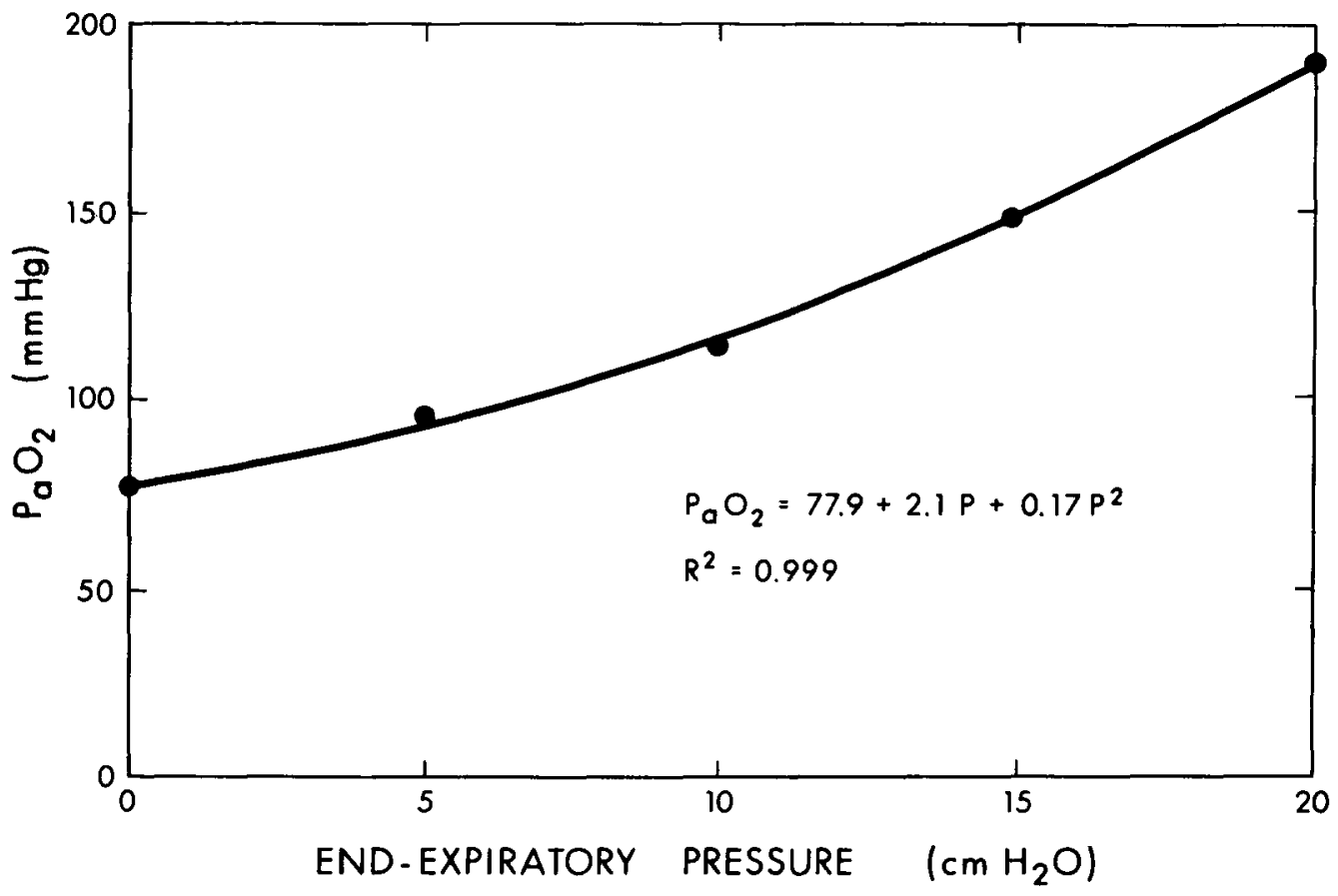

Figure 2. Graph demonstrating relationship between $0,5,10,15$, and $20 \mathrm{~cm} \mathrm{H}_{2} \mathrm{O}$ PEEP and associated mean levels of $\mathrm{PaO}_{2}$.

TABLE III

Changes in Right-to-Left Shunt ( $Q_{\mathrm{s}} / \dot{Q}$ t) Expressed as Percent Associated WITH $0,5,10,15$, AND $20 \mathrm{~cm} \mathrm{H} \mathrm{H}_{2} \mathrm{O}$ PEEP.

\begin{tabular}{|c|c|c|c|c|c|c|c|c|c|}
\hline Patient & IPPB & $5 \mathrm{~cm}$ & IPPB & $10 \mathrm{~cm}$ & IPPB & $15 \mathrm{~cm}$ & IPPB & $20 \mathrm{~cm}$ & IPPB \\
\hline R.G. & 48.5 & 48.1 & 43.6 & 32.5 & 39.5 & 32.4 & 47.8 & 36.9 & 50.1 \\
\hline G.M. & 38.4 & 42.9 & 42.5 & 39.5 & 39.7 & 36.5 & 39.0 & 22.0 & 39.0 \\
\hline 0.0 & 67.0 & 61.0 & 53.0 & 49.0 & 55.0 & 47.0 & 44.0 & 45.0 & 52.0 \\
\hline D.G. & 21.0 & 19.0 & 23.0 & 16.0 & 20.0 & 17.0 & 18.0 & - & - \\
\hline J.G & 41.8 & 36.2 & 一 & 35.2 & 36.4 & 29.3 & 49.3 & 19.9 & 35.7 \\
\hline H.W. & 62.4 & 66.0 & 64.1 & 68.1 & 69.7 & 66.0 & 64.7 & 56.4 & 72.8 \\
\hline W.W. & 40.0 & 27.2 & 29.3 & 22.1 & 35.7 & 16.3 & 29.7 & 16.3 & 32.3 \\
\hline F.L. & 47.2 & 43.2 & 37.7 & 36.6 & 33.7 & 32.0 & 40.5 & - & - \\
\hline J.M. & 61.5 & 35.3 & 40.3 & 36.1 & 42.8 & 33.5 & 39.5 & 32.7 & 40.4 \\
\hline E.S. & 34.4 & 30.0 & 32.3 & 30.5 & 36.8 & 26.8 & 34.7 & 14.1 & 33.7 \\
\hline F.S & 34.1 & 22.3 & 33.2 & 14.9 & 21.3 & 11.6 & 34.7 & 15.7 & 48.2 \\
\hline Mean & 45.2 & 39.2 & 40.0 & 35.0 & 39.1 & 31.7 & 40.2 & 28.8 & 45.0 \\
\hline S.D. & 14.0 & 15.0 & 11.9 & 15.0 & 14.0 & 15.2 & 12.0 & 14.9 & 12.7 \\
\hline $\begin{array}{l}P_{1} \\
P_{2}\end{array}$ & - & 0.04617 & $\begin{array}{r}\text { N.S. } \\
0 .\end{array}$ & $\begin{array}{l}0.00461 \\
35\end{array}$ & $\begin{array}{r}\text { N.S. } \\
0.0\end{array}$ & $\begin{array}{l}0.00122 \\
052\end{array}$ & $\begin{array}{l}\text { N.S. } \\
0.0\end{array}$ & $\begin{array}{l}0.00038 \\
318\end{array}$ & N.S. \\
\hline
\end{tabular}

tween individual patients in that on $5 \mathrm{~cm} \mathrm{H}_{2} \mathrm{O}$ PEEP, when compared to baseline IPPB values, $\mathrm{CO}$ increased slightly in three patients (R.G., J.G., E.S.) and in one of these on $10 \mathrm{~cm} \mathrm{H} \mathrm{H}_{2} \mathrm{O}$ PEEP. Other patients also showed slight increases in $\mathrm{CO}$ on 10,15 , and $20 \mathrm{~cm} \mathrm{H}_{2} \mathrm{O}$ PEEP when compared to the preceding interPEEP level. Patient O.O., in whom an increase in CO was demonstrated on 20 $\mathrm{cm} \mathrm{H}_{2} \mathrm{O}$ PEEP, showed little change in $\mathrm{CO}$ at all PEEP levels. 


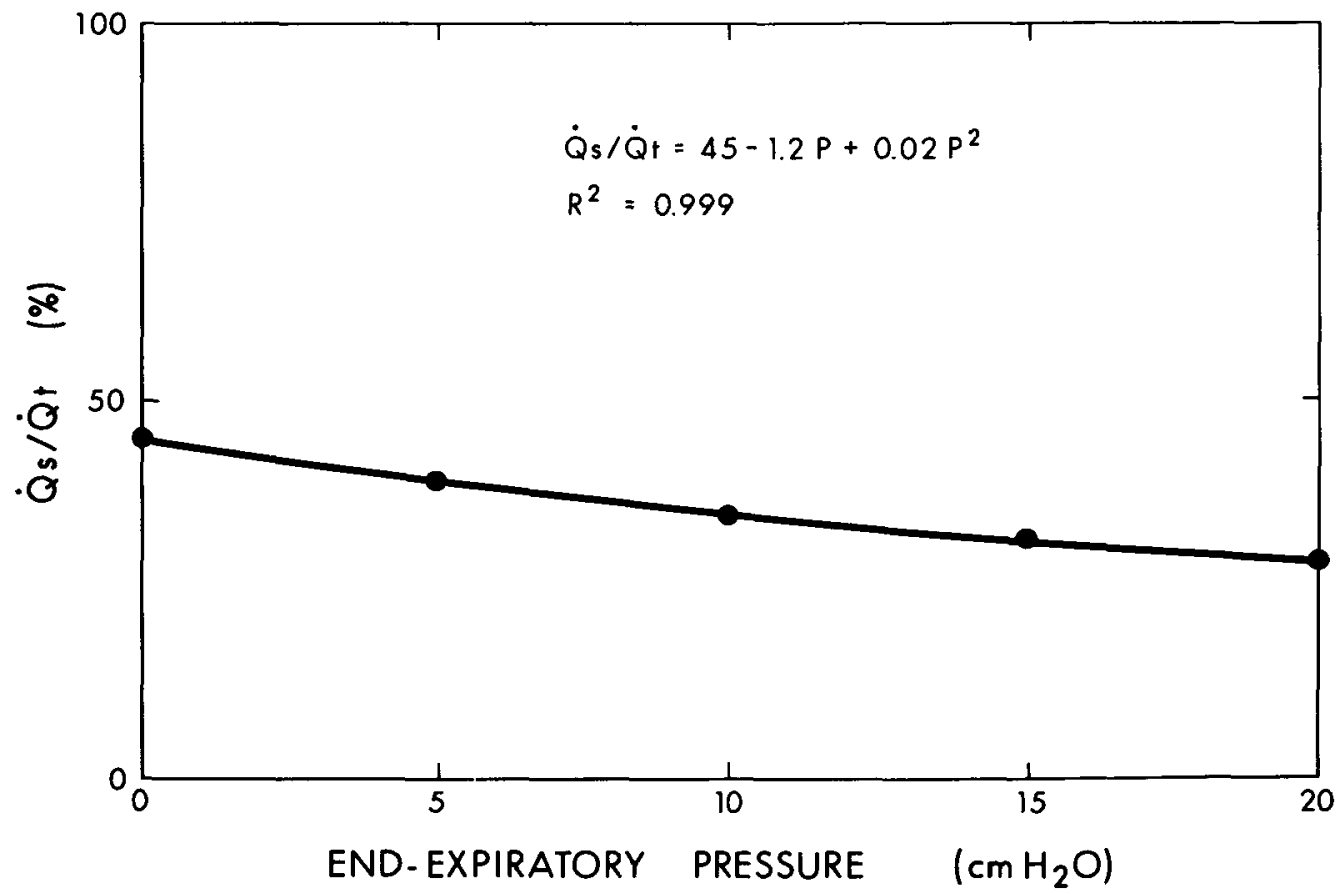

Figure 3. Graph demonstrating relationship between $0,5,10,15$, and $20 \mathrm{~cm}_{2} \mathrm{O}$ PEEP and associated levels of right-to-left shunt.

TABLE IV

Changes in Cardiac Outrut (Litres/Minute) Associated with 0, 5, 10 , 15, AND $20 \mathrm{~cm} \mathrm{H}_{2} \mathrm{O}$ PEEP.

\begin{tabular}{|c|c|c|c|c|c|c|c|c|c|}
\hline Patient & IPPB & $5 \mathrm{~cm}$ & IPPB & $10 \mathrm{~cm}$ & IPPB & $15 \mathrm{~cm}$ & IPPB & $20 \mathrm{~cm}$ & IPPB \\
\hline R.G. & 12.30 & 13.60 & 14.70 & 11.10 & 12.60 & 10.70 & 15.30 & 10.60 & 12.80 \\
\hline G.M. & 8.40 & 7.70 & 7.40 & 7.00 & 7.20 & 9.30 & 6.70 & 4.50 & 6.00 \\
\hline 0.0 & 6.10 & 5.25 & 6.00 & 5.65 & 5.10 & 5.10 & 5.10 & 5.80 & 4.90 \\
\hline D.G. & 6.55 & 6.00 & 5.90 & 5.40 & 5.85 & 5.30 & 4.65 & - & - \\
\hline J.G. & 5.11 & 5.66 & 5.52 & 6.42 & 7.02 & 4.81 & 5.30 & 3.70 & 5.60 \\
\hline H.W. & 6.08 & 3.16 & 5.94 & 3.10 & 5.38 & 4.50 & 5.88 & 3.95 & - \\
\hline W.W. & 4.60 & 4.40 & 4.53 & 4.58 & 5.75 & 4.23 & 5.32 & 4.21 & 5.10 \\
\hline F.L. & 9.25 & 8.35 & 8.30 & 6.40 & 7.70 & 5.40 & 6.95 & - & - \\
\hline J.M. & 6.60 & 6.20 & 5.75 & 5.20 & 5.80 & 3.90 & 4.85 & 3.15 & 5.00 \\
\hline E.S. & 10.10 & 11.60 & 11.20 & 10.80 & 10.00 & 7.60 & 8.50 & 6.90 & 10.00 \\
\hline F.S. & 3.90 & 3.60 & 3.70 & 3.40 & 3.80 & 3.05 & 4.10 & 2.65 & 4.60 \\
\hline Mean & 7.18 & 6.87 & 7.18 & 6.28 & 6.93 & 5.81 & 6.60 & 5.05 & 6.75 \\
\hline St. Dev. & 2.55 & 3.26 & 3.20 & 2.60 & 2.48 & 2.38 & 3.14 & 2.45 & 3.00 \\
\hline $\begin{array}{l}P_{1} \\
P_{2}\end{array}$ & & $\mathrm{NS}$ & $\begin{array}{r}\text { N.S. } \\
0.0\end{array}$ & $\begin{array}{l}0.04622 \\
358\end{array}$ & $\begin{array}{l}\text { N.S. } \\
0.0\end{array}$ & ${ }_{92}^{0.00582}$ & $\begin{array}{r}\text { N.S. } \\
0.0\end{array}$ & $\begin{array}{l}0.0036 \\
813\end{array}$ & N.S. \\
\hline
\end{tabular}

$\mathrm{O}_{2}$ Delivery (Table V): Mean $\mathrm{O}_{2}$ delivery closely followed the effects of PEEP on mean CO, progressively declining with each PEEP increment (Figure 5). Statistically significant changes in mean $\mathrm{O}_{2}$ delivery were not seen up to and including $10 \mathrm{~cm} \mathrm{H}_{2} \mathrm{O}$ PEEP. Variation between patients was again prominent. When compared to baseline IPPB values, six patients increased their $\mathrm{O}_{2}$ delivery on $5 \mathrm{~cm} \mathrm{H}_{2} \mathrm{O}$ PEEP. Two of these patients had a slightly increased $\mathrm{O}_{2}$ delivery 


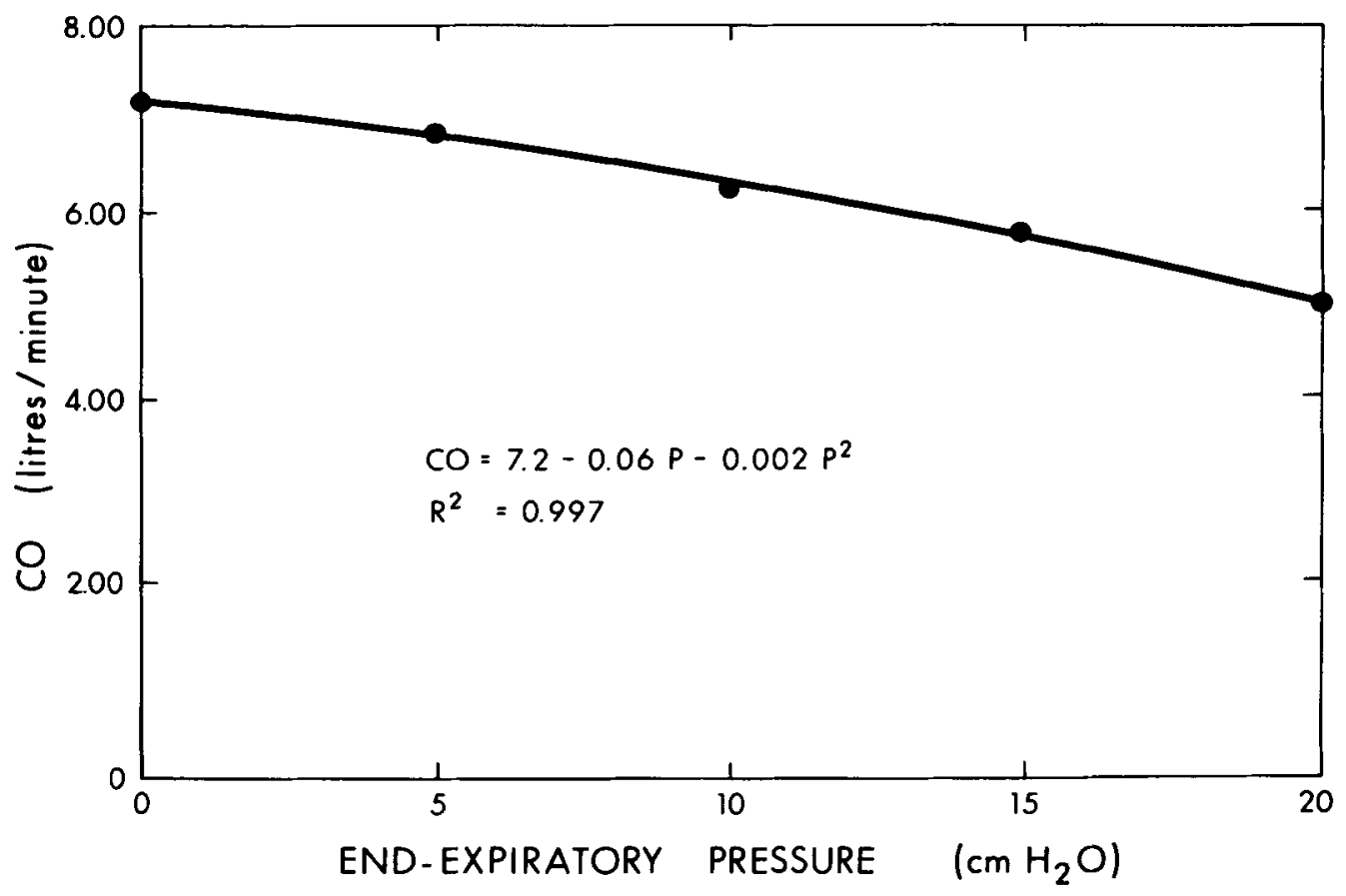

Figure 4. Graph demonstrating relationship between $0,5,10,15$, and $20 \mathrm{~cm} \mathrm{H}_{2} \mathrm{O}$ PEEP and associated mean levels of cardiac output.

TABLE V

Changes in Oxygen Delivery (mi O:/Minute) Associated with $0,5,10$, 15 , AND $20 \mathrm{~cm} \mathrm{H}_{2} \mathrm{O}$ PEEP.

\begin{tabular}{|c|c|c|c|c|c|c|c|c|c|}
\hline Patient & IPPB & $5 \mathrm{~cm}$ & IPPB & $10 \mathrm{~cm}$ & IPPB & $15 \mathrm{~cm}$ & IPPB & $20 \mathrm{~cm}$ & $\overline{I P P B}$ \\
\hline G. & 1684 & - & 1982 & 1547 & 1769 & 1522 & 2061 & 1524 & 1755 \\
\hline & 1120 & 1015 & 986 & & & 1198 & 863 & 629 & 772 \\
\hline .0. & 740 & 644 & 702 & 694 & 611 & 649 & 619 & 776 & 588 \\
\hline D.G. & 1129 & 1144 & 1097 & 1030 & 1101 & 998 & 875 & & \\
\hline J.G. & 656 & 745 & - & 8 & 912 & 64 & 705 & 509 & 769 \\
\hline H.V & 65 & 322 & 630 & 3 & 5 & 46 & 558 & 468 & 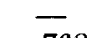 \\
\hline W.W. & 635 & 669 & 677 & 70 & 797 & 672 & 800 & 669 & 768 \\
\hline F.L. & 1198 & 1088 & 1108 & & 1010 & 71 & 930 & 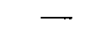 & \\
\hline J.M. & 820 & 903 & 766 & 7 & 772 & 5 & 662 & 486 & 679 \\
\hline E.S. & 1325 & 1535 & 1485 & 1447 & 1308 & 1032 & 1131 & 983 & 1329 \\
\hline F.S. & 672 & 676 & 6 & 6 & 712 & 60 & 671 & 501 & 774 \\
\hline Mean & 976 & 874 & 1006 & 882 & 951 & 821 & 898 & 727 & 929 \\
\hline St. Dev. & 354 & 33 & 440 & 355 & 352 & 325 & 419 & 343 & 400 \\
\hline & & . & \multicolumn{2}{|c|}{0.04821} & 0 & 6.0115 & \multicolumn{2}{|c|}{ S. ${ }^{0.02445}$} & \\
\hline
\end{tabular}

when compared to the preceding inter-PEEP IPPB level on $10 \mathrm{~cm} \mathrm{H}_{2} \mathrm{O} P E E P$. Two other patients (G.M., O.O.) had enhanced $\mathrm{O}_{2}$ delivery on $15 \mathrm{~cm} \mathrm{H} \mathrm{H}_{2} \mathrm{O}$ PEEP. In one of these latter patients (O.O.), $\mathrm{O}_{2}$ delivery was maintained up to and including $20 \mathrm{~cm} \mathrm{H}_{2} \mathrm{O}$ PEEP.

Despite observed increases in $\mathrm{P}_{\mathrm{a}} \mathrm{O}_{2}$ with PEEP increments, mean calculated peripheral-capillary $\mathrm{PO}_{2}$ increased only slightly with PEEP and these changes 


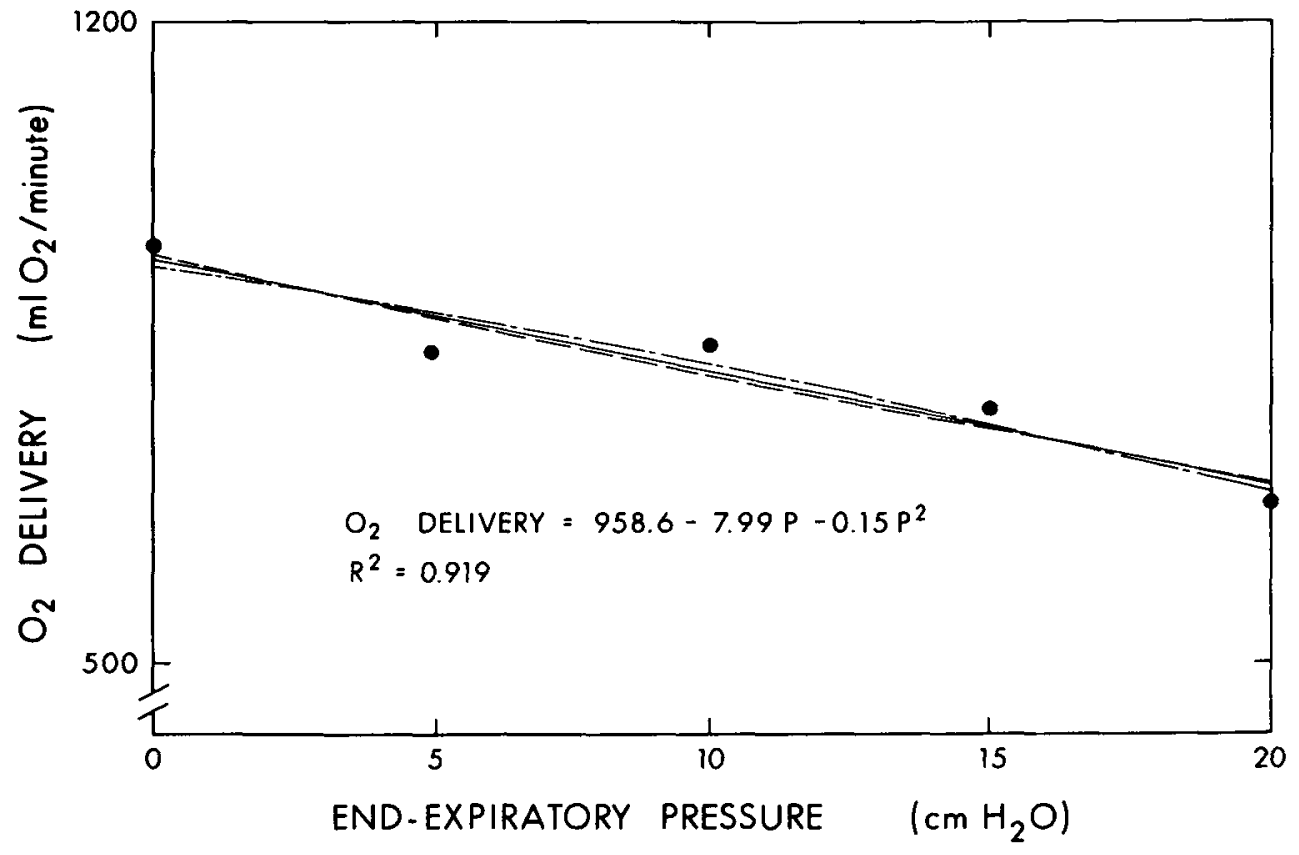

Frgure 5. Graph demonstrating best fit parabolic, linear and exponential relationships between $0,5,10,15$, and $20 \mathrm{~cm} \mathrm{H}_{2} \mathrm{O}$ PEEP and associated mean levels of oxygen delivery. The parabolic equation shown provides the best $R^{2}$ value.

were not statistically significant (Figure 6 ). The mean capillary to mitochondrial gradient was therefore not significantly improved.

$P a C O_{2}, p H, C_{d y n}, S A P, V_{D} / V_{T}$ : Mean baseline values for $\mathrm{PaCO}_{2}(28 \mathrm{~mm} \mathrm{Hg}$ ). and $\mathrm{pH}$ (7.48) did not change significantly throughout the studies. Mean baseline $\mathrm{C}_{\mathrm{dyn}}\left(27.8 \mathrm{ml} / \mathrm{cm} \mathrm{H}_{2} \mathrm{O}\right)$ reflected marked lung stiffness, but likewise failed to show statistically significant changes with PEEP. Mean SAP ( $90.1 \mathrm{~mm} \mathrm{Hg}$ ) was not altered significantly until $20 \mathrm{~cm} \mathrm{H}_{2} \mathrm{O}$ PEEP was applied when it declined to $83.8 \mathrm{~mm} \mathrm{Hg}$. In the five patients in which $\mathrm{V}_{\mathrm{D}} / \mathrm{V}_{\mathrm{T}}$ was measured, no PEEPassociated change from the baseline value ( 0.58$)$ could be demonstrated.

Incidental Observations and Complications: The first expired breath after cessation of PEEP was higher than the PEEP tidal volumes in all cases. Randomization of the order of PEEP application did not appear materially to affect any of the measured variables. No complications such as pneumothoraces occurred.

\section{Discussion}

This study demonstrates that although $\mathrm{PaO}_{2}$ can be improved in most ARDS patients with application of PEEP, the increase in $\mathrm{PaO}_{2}$ is generally purchased at the price of diminishing cardiac output. Depending on the increase in $\mathrm{O}_{2}$ content relative to decline of cardiac output, $\mathrm{O}_{2}$ delivery to peripheral tissues may be slightly enhanced, remain unchanged from IPPB levels, or fall. 


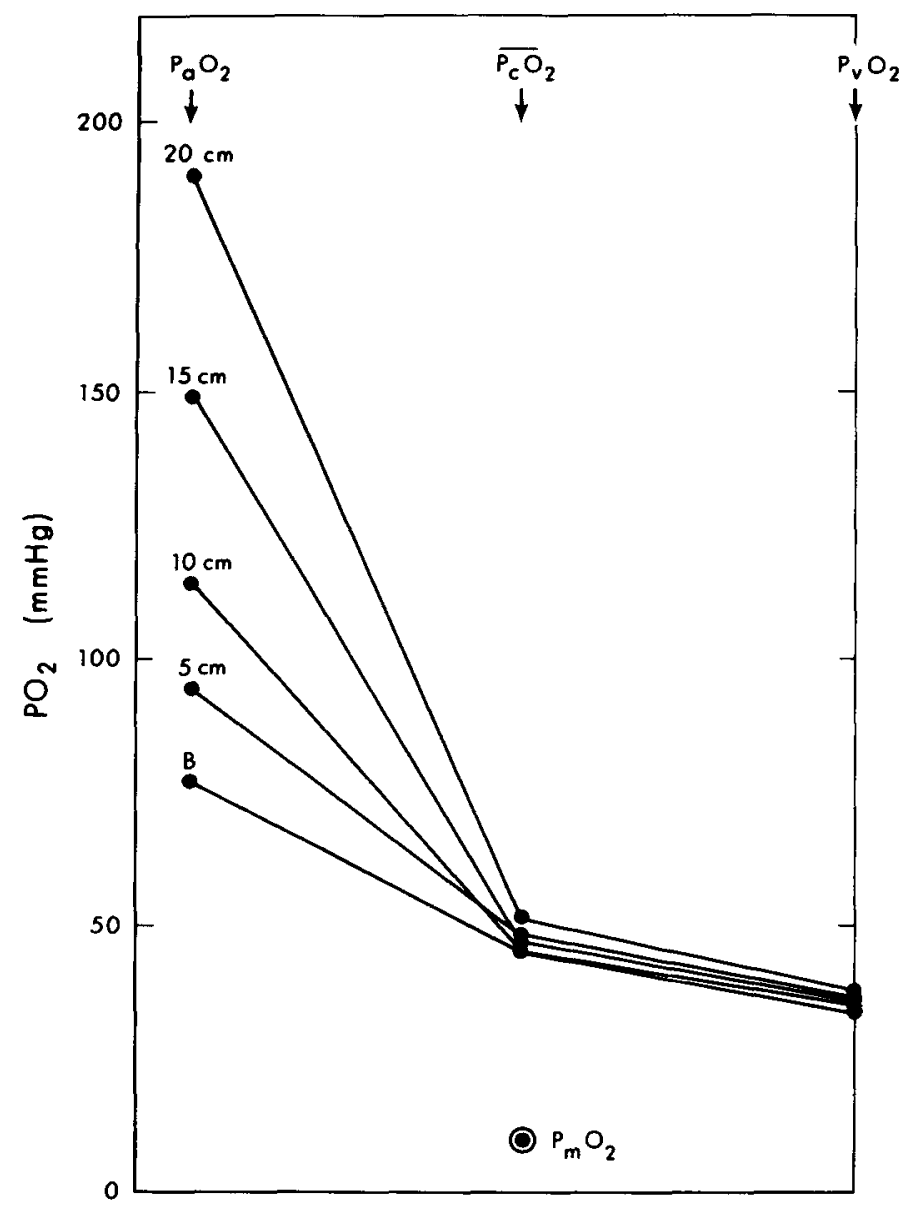

Figure 6. Graph demonstrating levels of $\mathrm{PaO}_{2}, \mathrm{PcO}_{2}$, and $\mathrm{PvO}_{2}$ for $0,5,10,15$, and 20 $\mathrm{cm} \mathrm{H}_{2} \mathrm{O}$ PEEP. Although small increases in $\mathrm{PcO}_{2}$ occurred on application of 15 and $20 \mathrm{~cm}$ $\mathrm{H}_{2} \mathrm{O}$ PEEP, the difference between these levels and IPPB was not significant. $\mathrm{PmO}_{2}$ refers to a speculative value for mitochondrial $\mathrm{O}_{2}$ tension. ${ }^{13}$

Considerable interpatient variation in the effect of PEEP on $\mathrm{PaO}_{2}$ was evident. A wide range in critical opening pressures for shunting gas exchange units likely accounts for this observation. The progressive increase in mean $\mathrm{PaO}_{2}$ with diminution in shunt is probably due to recruitment of previously closed gas exchange units through elevation in functional residual capacity (FRC). ${ }^{7,9}$ It may also be due in part to a more beneficial distribution of blood flow or an absolute reduction in pulmonary perfusion. We have shown that in Xenon-133 ventilation/perfusion studies in the ARDS oleic acid model, the major functional basis for shunt reduction appears to be enhancement of ventilation to previously shunting regions, with elevation of FRC.

The decline in mean CO noted with PEEP might have been predicted from earlier experiments that showed impairment of $\mathrm{CO}$ with increases in mean intrathoracic pressure. ${ }^{10}$ Although it has been stated that any tendency toward a 
PEEP-induced fall in $\mathrm{CO}$ is minimized in patients with stiff lungs, ${ }^{4}$ the haemodynamic effects of PEEP are undoubtedly the end result of a variety of factors. These include: transmitted airway pressure acting on either great veins ${ }^{14}$ or alveolar vessels, ${ }^{15}$ the presence of a normal or supernormal effective circulating fluid volume ${ }^{16}$ and intact cardiovascular reflex activity (Jones and King, In Press, J. Appl. Physiol.).

Because most of the patients studied were on or near the flat upper part of their haemoglobin dissociation curves, mean $\mathrm{O}_{2}$ delivery closely followed changes in cardiac output produced by PEEP, progressively falling with each PEEP increment. However, it is apparent that for any individual patient $\mathrm{O}_{2}$ delivery may be enhanced, remain unchanged, or decline with PEEP application, depending upon the relationship between increased $\mathrm{O}_{2}$ content and decreased $\mathrm{CO}$. Despite fall in $\mathrm{CO}$ and $\mathrm{O}_{2}$ delivery at higher PEEP levels, $\mathrm{pH}$ remained unaltered. With the exception of one patient (F.S.) $\mathrm{CO}$ even with $20 \mathrm{~cm} \mathrm{H}_{2} \mathrm{O}$ PEEP, did not fall to the point where anaerobic tissue metabolism would be anticipated to occur. PEEP application is associated with a decline in peripheral $\mathrm{O}_{2}$ consumption ${ }^{8,17}$ and, although the mechanism for this is obscure, this phenomenon may also account in part for the absence of anaerobic metabolism. $\overline{\mathrm{PcO}_{2}}$ remained essentially unchanged despite significant elevations in $\mathrm{PaO}_{2}$. Although no attempt was made to assess the effect of PEEP on individual tissue oxygenation, the whole body mean peripheral-capillary to mitochondrial oxygen gradient was unaffected by PEEP. This of course assumes no change in mitochondrial $\mathrm{PO}_{2}$ during PEEP application. However, in light of previous reports showing that $\mathrm{O}_{2}$ consumption decreases during $\mathrm{PEEP}$, the lack of any significant change in $\overline{\mathrm{PcO}_{2}}$ would likely produce an $\mathrm{O}_{2}$ supply in excess of tissue demands.

$\mathrm{V}_{\mathrm{D}} / \mathrm{V}_{\mathrm{T}}$ was unchanged with PEEP application in this and other studies conducted with patients; ${ }^{18}$ however, in dogs with the oleic acid induced ARDS, we have demonstrated an increase in $\mathrm{V}_{\mathrm{D}} / \mathrm{V}_{\mathrm{T}}$ with $\mathrm{PEEP}$, and at 15 and $20 \mathrm{~cm} \mathrm{H}_{2} \mathrm{O}$ levels, $\mathrm{PaCO}_{2}$ may rise. These observations in animals are probably based on the increase in both anatomical and physiological dead space that occurs with high ventilation volumes which in turn result in diminished effective alveolar ventilation. ${ }^{19}$

Although it has been postulated that PEEP may "squeeze" water out of the lung and thus produce an improvement in compliance, ${ }^{8}$ mean $\mathrm{C}_{\text {dyn }}$ did not change with the application of PEEP in the eleven patients studied. The short term nature of this study may have mitigated against being able to demonstrate any significant change in this parameter.

Systematic arterial pressure was unaltered by PEEP application until $20 \mathrm{~cm}$ $\mathrm{H}_{2} \mathrm{O}$ PEEP was applied suggesting that vascular reflexes were intact and that effective circulating fluid volume was adequate in most patients. More importantly, it also demonstrates that SAP represents an unreliable index of the effects of PEEP on the circulation and, in particular, cardiac output and $\mathrm{O}_{2}$ delivery. The duration of increased end-expiratory pressure in this study was only 20 minutes for each application, a time period that may have been insufficient for 5 and $10 \mathrm{~cm} \mathrm{H}_{2} \mathrm{O}$ PEEP to complete their redistribution of ventilation and allow for cardiovascular adjustments. If this were the case, then prolonged application 
of low PEEP levels may be expected to increase $\mathrm{O}_{2}$ delivery to higher levels than was observed in this study. Also, $\mathrm{O}_{2}$ delivery would be expected to increase more at low PEEP levels if the pre-PEEP $\mathrm{PaO}_{2}$ was low enough to produce $\mathrm{O}_{2}$ saturations on the steep part of the $\mathrm{O}_{2}$ dissociation curve. Small increases in $\mathrm{PaO}_{2}$ would then produce larger increases in $\mathrm{O}_{2}$ content.

The precise role of PEEP in support of hypoxaemic patients remains to be clarified: It is possible that the ultimate place for PEEP in the therapeutic armamentarium will be in the sustenance of high lung volumes with preservation of pulmonary architectural integrity. Despite improvement in $\mathrm{PaO}_{2}$ and the welcome possibility of being able to reduce inspired oxygen concentration, $\mathrm{O}_{2}$ delivery to peripheral tissues is usually reduced when levels greater than $10 \mathrm{~cm} \mathrm{H} \mathrm{H}_{2} \mathrm{O} P E E P$ are applied. PEEP levels of $10 \mathrm{~cm} \mathrm{H}_{2} \mathrm{O}$ or less were capable in this study of increasing $\mathrm{PaO}_{2}$ to levels which nearly saturated haemoglobin with oxygen. This increase in $\mathrm{O}_{2}$ content, coupled with only minor decreases in cardiac output, make low PEEP levels relatively safe, but interpatient variation in response to all levels of PEEP makes careful monitoring mandatory.

\section{SUMMARY}

The effects of $5,10,15$, and $20 \mathrm{~cm} \mathrm{H}_{2} \mathrm{O}$ positive end-expiratory pressure were studied in eleven patients with the adult respiratory distress syndrome (ARDS). Arterial $\mathrm{PO}_{2}$ increased but cardiac output and $\mathrm{O}_{2}$-delivery decreased during 10 , 15 and $20 \mathrm{~cm} \mathrm{H}_{2} \mathrm{O}$ PEEP. With $5 \mathrm{~cm} \mathrm{H} \mathrm{H}_{2} \mathrm{O}$ PEEP there were no significant changes in these variables. Calculated mean peripheral-capillary $\mathrm{PO}_{2}$ remained essentially unaltered even though arterial $\mathrm{PO}_{2}$ increased progressively with PEEP.

\section{RÉSUMÉ}

Nous avons étudié les effets d'une pression positive de fin d'expiration de 5, 10 , 15 et $20 \mathrm{~cm} \mathrm{H}_{2} \mathrm{O}$ chez onze malades souffrant du syndrome de détresse respiratoire de l'adulte (ARDS).

La $\mathrm{PO}_{2}$ artérielle a augmenté mais le débit cardiaque et la quantité d'oxygène disponible ont diminué lors de l'usage de 10,15 et $20 \mathrm{~cm}$ d' $\mathrm{H}_{2} \mathrm{O}$ de PEEP. Lors de l'usage de $5 \mathrm{~cm} \mathrm{H}_{2} \mathrm{O}$ de $\mathrm{PEEP}$, nous n'avons observé aucun changement de ces facteurs. La moyenne calculée de la $\mathrm{PO}_{2}$ capillaire périphérique est demeurée inchangée même si la $\mathrm{PO}_{2}$ a augmenté progressivement avec la PEEP.

\section{ACKNOWLEDGMENTS}

The authors would like to express their gratitude to Dr. M. Campbell, Dr. J.V. Weil, Dr. D.G. Ashbaugh and Dr. P. Lynne-Davies for their critical review of this manuscript. The nurses and respiratory technologists of the University Hospital Intensive Care Unit provided invaluable assistance during the studies. Thanks are also extended to Mr. W. Giles and Miss M. Herbert for technical and secretarial services. Statistical analysis was performed by Dr. Michael Grace. 


\section{REFERENCES}

I. Ashbaugh, D.G., Bigelow, D.B., PetTy, T.L., \& Levine, B.E. Acute respiratory distress in adults. Lancet 2: 319 (1967).

2. Moore, F.D., Lyons, J.H., Puerce, E.C., et al. Post-traumatic pulmonary insufficiency. W.B. Saunders, Toronto (1969).

3. Eiseman, B. \& Astraugh, D.G. (editors) Pulmonary effects of nonthoracic trauma. Proceedings of a conference conducted by the committee on trauma, division of Medical Sciences National Academy of Sciences, National Research Council. J. Trauma 8: 625ff (1968).

4. Petry, T.L. \& Ashbaugh, D.G. The adult respiratory distress syndrome. Chest 60: 233 (1971).

5. Nash, G., Blennerhassett, B., Pontoppidan, H. Pulmonary lesions associated with oxygen therapy and artificial ventilation. New Engl. J. Med. 276: 368 (1967).

6. Ashraugh, D.G., PetTy, T.L., Bigelow, D.B., \& Hill, T.M. Continuous positive pressure breathing (CPPB) in adult respiratory distress syndrome. J. Thor. \& Cardiovasc. Surg. 57: 31 (1969).

7. McIntyre, R.W., Laws, A.K., \& Ramachandran, P.R. Positive expiratory pressure plateau: improved gas exchange during mechanical ventilation. Canad. Anesth. Soc. J. 16: 477 ( 1969 ).

8. Kumar, A., Falke, K.I., Geffin, B., Aldredge, C.F., Laver, M.B., Lowerstein, E., \& Pontoppidan, H. Continuous positive-pressure ventilation in acute respiratory failure. New Engl. J. Med. 283: 1430 (1970).

9. Falke, K.J., Pontoppidan, H., Kumar, A., Leith, D.E., Geffin, B., \& Laver, M. Ventilation with end-expiratory pressure in acute lung disease. J. Clin. Invest. 51: 2315 (1972).

10. Cournand, A., Motley, H.L., Werko, L. et al. Physiological studies of the effects of intermittent positive pressure breathing on cardiac output in man. Amer. J. Physiol. 152: 162 (1948).

11. LuTCH, J.S. \& MURRAY, J.F. Continuous positive-pressure ventilation: effects on systemic oxygen transport and tissue oxygenation. Ann. Int. Med. 76: 193 (1972).

12. Riley, R.L. \& Cournand, A. Analysis of factors affecting partial pressures of oxygen and carbon dioxide in gas and blood of lungs: Theory. J. Appl. Physiol. 4: 77 (1951).

13. Flenley, D,C. The rationale of oxygen therapy. Lancet $1: 270$ (1967).

14. Salzano, J. \& Hall, F.G. Cardiopulmonary effects of continuous pressure breathing in hypothermic dogs. J. Appl. Physiol. 20: 669 (1965).

15. DALY, W.J. Pulmonary diffusing capacity for carbon monoxide and topography of perfusion during changes in alveolar pressure in man. Amer. Rev. Resp. Dis. 99: 548 (1969).

16. Morgan, D.C., Crawford, E.W., \& Guntheroth, W.G. The hemodynamic effects of changes in blood volume during intermittent positive pressure ventilation. Anesthesiology 30: 297 (1969)

17. Uzawa, T. \& Asmbaugh, D.G. Continuous positive pressure breathing in acute hemorrhagic pulmonary edema. J. Appl. Physiol. 26: 427 (1969).

18. SEed, R.F., SYKes, M.K., \& FINLAY, W.I. The effect of variations in end-expiratory inflation pressure on cardiorespiratory function before and after open chest surgery. Brit. J. Anaesth, 42: 488 (1970).

19. Martin, H.B. \& Proctor, D.F. Pressure volume measurements on dog bronchi. J. Appl. Physiol. 13: 337 (1958). 